\title{
Meningkatkan Kualitas Pembelajaran IPS dengan Model Kooperatif Course Review Hooray di SD Negeri 10 Kepahiang
}

\author{
Supriogi \\ SD Negeri 10 Kepahiang \\ juliahsupriogi@yahoo.com
}

\begin{abstract}
At SD Negeri 10 Kepahiang, there are still teachers who haven't implemented innovative learning, still became the center of the class, and students were too passive. The learning outcomes became mimimum. Because action is needed to improve the quality of learning, and Course Review Hooray might be the answer. The purpose of this study was to improve teaching skills, increase student activity, and improve learning competencies in Social Science. The study was divided into three cycles, each cycle divided into planning, implementing, observing and reflecting. The results in Cycle I, the student learning outcomes obtained a 44\% completeness. In Cycle II, the learning outcomes increased with a completeness of $67 \%$. In Cycle III, the average value of student learning outcomes obtained a completeness of 93\%. Thus, conclusion can be drawn, by using the Course Review Hooray Cooperative Learning Model the quality of Social Science has increased impressively.
\end{abstract}

Keywords: Quality of Learning, Course Review Hooray.

\section{Pendahuluan}

Permediknas RI Nomor 22 tahun 2006 menjelaskan Ilmu Pengetahuan Sosial menjadi salah satu pelajaran yang diterima siswa dari Sekolah Dasar sampai dengan Sekolah Menengah Pertama. Mata Pelajaran IPS bertujuan untuk mengkaji konsep, peristiwa, fakta, serta generalisasi yang erat hubungannya dengan isu sosial. Wahyudi dalam Hidayati dkk. (2008) menjelaskan bahwa IPS merupakan Ilmu Pengetahuan yang menelaah berbagai masalah yang timbul di masyarakat dikarenakan perkembangan IPTEK. Itulah kenapa Penelitian Tindakan Kelas untuk pelajaran IPS sangat menarik untuk dicoba.

Setelah melakukan pengamatan terhadap keterampilan guru dalam mengajar, aktivitas siswa didalam kelas, dan hasil belajar mata pelajaran IPS di kelas IV SD Negeri 10 Kepahiang ditemukan beberapa permasalahan. Permasalahan tersebut diantaranya pada saat pembelajaran tengah berlangsung siswa memiliki tendensi tidak memperhatikan penjelasan dari guru. Akhirnya siswa tidak mampu menjawab pertanyaan maupun permasalahan yang disampaikan oleh guru. Pembelajaran masih sangat berpusat pada guru serta belum ditemukannya pendekatan yang lebih inovatif.

Setelah memahami latar belakang masalah yang timbul pada Mata Pelajaran IPS, serta hasil diskusi peneliti dengan guru kelas IV SD Negeri 10 Kepahiang, maka metode yang dipilih untuk meningkatkan kualitas pembelajaran Mata Pelajaran IPS adalah dengan Model Pembelajaran Secara Kooperatif Course Review Hooray.

Aksiwi dan Sagoro (2014) menjelaskan Model Pembelajaran Secara Kooperatif Course Review Hooray merupakan model pembelajaran dengan pengujian 
pemahaman siswa menggunakan kotak yang berisi nomor untuk menuliskan jawabannya. Siswa yang lebih dulu mendapatkan tanda atau jawaban benar langsung berteriak "horay" atau yel-yel yang telah dipersiapkan sebelumnya. Disamping itu Menurut Stahl dalam Solihatin dan Raharjo (2007) model pembelajaran kooperatif menempatkan siswa sebagai bagian dari suatu sistem kerja sama dalam mencapai suatu hasil yang optimal dalam belajar.

Pebriansyah (2009) dalam penelitiannya "Upaya Peningkatan Prestasi Belajar Siswa Kelas VIIIA SMPN 1 Ngawen pada Mata Pelajaran IPS Materi Sejarah melalui Penerapan Model Pembelajaran Course Review Huray Tahun Pelajaran 2008-2009" menyimpulkan bahwa dengan bantuan metode Course Review Huray dapat secara dramatis meningkatkan hasil belajar siswa. Ini dibuktikan di Siklus I, yang mana ketuntasan belajar secara klasikal mencapai $61,54 \%$ dan di Siklus II ketuntasan belajar secara klasikan mencapai $82,05 \%$, dan nilai hasil belajar yang diatas KKM mencapai lebih dari 75\%. Selain itu Aksiwi dan Sagoro (2014) yang pada jurnalnya juga menyimpulkan berdasarkan hasil penelitian, dapat diambil kesimpulan bahwa penerapan Metode Pembelajaran Course Review Horay dapat meningkatkan aktivitas dan hasil belajar jurnal penyesuaian pada siswa kelas X Akuntansi SMK Muhammadiyah 2 Moyudan Tahun Ajaran 2013/2014. Peningkatan ini terlihat dari kenaikan persentase Aktivitas dan Hasil Belajar Siswa dalam pembelajaran Akuntansi di kelas dengan materi Jurnal Penyesuaian.

Pada Penelitian Tindakan Kelas pelajaran IPS ini, pengamatan dilakukan pada keterampilan mengajar guru, aktivitas siswa dalam kelas, serta hasil belajar Mata Pelajaran IPS, dan ditemukan beberapa kendala. Pada saat pembelajaran di dalam kelas, para siswa tidak memperhatikan pembelajaran. Imbasnya, siswa mengalami kendala ketika guru memberikan pertanyaan. Pembelajaran didalam kelas secara total berpusat pada guru tanpa adanya pendekatan yang lebih inovatif.

Model Pembelajaran Secara Kooperatif Course Review Hooray dalam penelitian dipilih karena dengan Model Pembelajaran ini bisa meningkatkan aktivitas siswa serta mampu menciptakan kondisi belajar yang lebih kondusif dan menyenangkan.

\section{Metode}

Penelitian ini menggunakan metode Penelitian Tindakan Kelas (PTK). Suyanto dalam Subyantoro (2009) menjelaskan Penelitian Tindakan Kelas adalah penelitian yang bersifat reflektif dengan cara melakukan tindakan tertentu agar bisa memperbaiki serta meningkatkan pembelajaran secara tepat dan profesional. Tahapan PTK dibagi menjadi 4 yaitu, Perencanaan, Pelaksanaan, Pengamatan, dan Refleksi. Subyek dari penelitian ini merupakan siswa kelas IV yang berjumlah 27 siswa, terdiri dari 14 laki-laki dan 13 perempuan. Penelitian ini dilakukan secara berkolaborasi antara peneliti dengan teman sejawat yang bertindak sebagai observer.

Teknik pengumpulan data pada penelitian ini menggunakan beberapa metode. Menurut Gulo (2002) pengumpulan data bisa dilakukan dengan menggunakan metode sebagai berikut: 1) Metode Observasi yang bertujuan untuk mengumpulkan dengan seksama dan sistematis, 2) Metode Dokumentasi yang dapat berbentuk, gambar, video, atau catatan tertulis tentang berbagai kegiatan atau peristiwa pada waktu yang lalu, 3) Metode Wawancara yang menjadi komunikasi langsung peneliti dengan responden, 4) Metode Tes yang mana Poerwanti (2008) menjelaskan seperangkat tugas yang harus dikerjakan untuk menjadi nilai ukur tingkat pemahaman terhadap cakupan materi yang dilakukan berupa tes lisan ataupun tes tertulis. 
Instumen yang digunakan dalam penilitian ini ada beberapa macam: 1) Lembar Observasi yang digunakan dalam pengamatan serta pencatatan yang difokuskan pada perilaku tertentu, 2) Bukti Dokumentasi yang berupa gambar/foto, video, atau catatan tertulis tentang kegiatan yang berlangsung selama penelitian berlangsung, 3) Lembar Wawancara sebagai alat pengumpulan data dengan cara memberikan pertanyaan lisan kepada subjek yang diteliti, 5) Lembar Tes yang menjadi instrumen yang digunakan agar menghasilkan jawaban yang dijadikan penetapan skor angka.

Adapun teknik analisis data yaitu kuantitatif dan kualitatif. Teknik kuantitatif dengan menggunakan analisis deskriptif merupkan suatu metode penelitian yang bersifat menggambarkan kenyataan yang sesuai dengan data yang diperoleh. Analisis tingkat keberhasilan diperoleh dengan menggunakan rumus sebagai berikut:

Data hasil belajar siswa

Skor $=\frac{\mathrm{B}}{\mathrm{N}} \times 100($ Skor Mulai $0-100)$

Keterangan:

B: banyak soal yang benar

$\mathrm{N}$ : banyaknya soal

Poerwanti (2008)

Data nilai rata-rata belajar siswa

$\mathrm{X}=\frac{\sum x}{\sum N} \times 100 \%$

Keterangan:

$\mathrm{X} \quad$ : nilai rata-rata

$\sum x$ : jumlah semua nilai siswa

$\sum N$ : jumlah siswa

Data ketuntasan belajar siswa

Aqib (2008)

$\mathrm{P}=\frac{\sum \text { Jumlah siswa yang tuntas belajar }}{\sum \text { Jumlah siswa }} \times 100 \%$

Keterangan:

P: persentase

Aqib (2008)

Tabel 1. Ketuntasan Persentase Belajar Siswa

\begin{tabular}{ccc}
\hline $\begin{array}{c}\text { Pencapaian Tujuan } \\
\text { Pembelajaran }\end{array}$ & Kualifikasi & $\begin{array}{c}\text { Tingkat Keberhasilan } \\
\text { Pembelajaran }\end{array}$ \\
\hline $85 \%-100 \%$ & Sangat Baik (SB) & Berhasil \\
\hline $65 \%-84 \%$ & Baik (B) & Berhasil \\
\hline $55 \%-64 \%$ & Cukup (C) & Tidak Berhasil \\
\hline $0 \%-54 \%$ & Kurang (K) & Tidak Berhasil \\
\hline
\end{tabular}

Teknik kualitatif merupakan data kualitalif yang diperoleh dari menganalisis lembar observasi yang telah diisi pada saat pembelajaran berlangsung. Kriteria deskriptif presentasi dikelompokkan dalam empat kategori yaitu sangat baik, baik, cukup dan kurang. Untuk lembar pengamatan keterampilan guru dan aktivitas siswa menggunakan skala penilaian. Menurut Sudjana (2009) Skala penilaian merupakan alat untuk mengukur nilai, sikap, minat dan perhatian. Skala nilai bisa juga dikategorikan sangat baik, baik, cukup dan kurang dengan angka 4, 3, 2 dan 1 .

Tabel 2. Kualifikasi Kategori Nilai Keterampilan Guru dan Aktivitas Siswa

\begin{tabular}{ccc}
\hline Skor Penilaian & Kualifikasi & $\begin{array}{c}\text { Tingkat Keberhasilan } \\
\text { Pembelajaran }\end{array}$ \\
\hline $3,1-4$ & Sangat Baik $(\mathrm{Sb})$ & Berhasil \\
\hline $2,1-3$ & Baik (B) & Berhasil \\
\hline
\end{tabular}




\begin{tabular}{ccc}
\hline $1,1-2$ & Cukup $(\mathrm{C})$ & Tidak Berhasil \\
\hline $0,1-1$ & Kurang $(\mathrm{K})$ & Tidak Berhasil \\
\hline
\end{tabular}

\section{Hasil}

Data pra Siklus menunjukkan hasil pembelajaran IPS yang tergolong rendah.

Tabel 3. Tabel Hasil Belajar Siswa Pra Siklus

\begin{tabular}{ccc}
\hline No & Pencapaian & Data Awal \\
\hline 1. & Rata-rata & 52 \\
\hline 2. & Nilai Terendah & 25 \\
\hline 3. & Nilai Tertinggi & 80 \\
\hline 4. & Tidak Tuntas & $67 \%$ \\
\hline 5. & Tuntas & $33 \%$ \\
\hline
\end{tabular}

Berdasarkan hasil pengamatan terhadap keterampilan guru serta aktivitas siswa, dan hasil belajar pada pra Siklus dapat dirumuskan akara masalah diantaranya: pembelajaran masih berpusat pada guru dan lebih banyak menggunakan buku paket sehingga menyebabkan siswa cepat bosan. Setelah mengkaji akar masalah maka peneliti berkolaborasi dengan teman sejawat dan menetapkan alternatif Model Pembelajaran Secara Kooperatif Course Review Hooray, yang mana pada metode ini berpusat pada siswa.

\section{Deskripsi Data Pelaksanaan Tindakan Siklus I}

Perencanaan

Pada tahap perencanaan telah direncanakan dan dipersiapkan hal-hal seperti, menyusun RPP dengan materi Sumber Daya Alam yang ada di Indonesia, sesuai dengan refleksi Siklus I, kemudian mempersiapkan sumber dan media pembelajaran, selanjutnya menyiapkan alat evaluasi dan yang terakhir menyiapkan lembar observasi.

Pelaksanaan

Siklus I dilaksanakan pada Selasa tanggal 4 Februari 2020 selama 2 jam pelajaran $(2 \times 35$ menit $)$ Peneliti dan guru kelas IV mengamati proses pembelajaran. Pelaksanaan Siklus I mengacu pada RPP yang telah direncanakan pada tahap perencanaan.

\section{Pengamatan}

Hasil pengamatan terhadap keterampilan guru: berdasarkan pengamatan di Siklus I, keterampilan guru dalam pembelajaran mendapatkan skor 2,6 berkategori baik. Keterampilan guru merancang RPP dengan menggunakan Model Pembelajaran Secara Kooperatif Course Review Hooray memperoleh skor 4 berkategori sangat baik. Hasil pengamatan yang diperoleh selama proses pembelajaran, siswa memperoleh skor rata-rata 2,3 berkategori baik. Antusias siswa mengikuti pembelajaran kooperatif tipe Course Review Hooray memperoleh skor 2,2 berkategori baik. Siswa belum terbiasa dengan Model Pembelajaran yang diterapkan guru sehingga siswa canggung dalam pembelajaran. Sehingga banyak dijumpai beberapa siswa asyik bermain sendiri pada saat pembelajaran. Keaktifan siswa menyampaikan pendapat memperoleh skor 2,1 berkategori baik. ini dikarenakan siswa masih malu-malu menyampaikan pendapat sebelum ditunjuk oleh guru. Sedangkan keaktifan menjawab pada saat kerja kelompok memperoleh rata-rata skor 2,3 berkategori baik. siswa yang aktif menjawab pada saat kerja kelompok lebih didominasi oleh siswa yang pandai sedangkan yang lainnya cenderung pasif. 
Hasil Belajar Siswa

Tabel 4. Tabel Hasil Belajar Siklus I

\begin{tabular}{cccc}
\hline No & Pencapaian & Data Awal & Siklus I \\
\hline 1. & Rata-rata & 52 & 66 \\
\hline 2. & Nilai Terendah & 25 & 40 \\
\hline 3. & Nilai Tertinggi & 80 & 90 \\
\hline 4. & Tidak Tuntas & $67 \%$ & $56 \%$ \\
\hline 5. & Tuntas & $33 \%$ & $44 \%$ \\
\hline
\end{tabular}

Dari tabel di atas terlihat bahwa setelah dilakukan proses pembelajaran dengan Model Course Review Hooray terdapat perubahan hasil belajar dari pra Siklus yaitu diperoleh rata-rata nilai 66 dengan nilai tertinggi 90 dan nilai terendah 40. Pada Siklus I, persentase ketuntasan siswa dalam bejar hanya mencapai $44 \%$. Sedangkan yang belum mencapai ketuntasan belajar mencapai 56\%, maka perlu dilakukan perbaikan di Siklus II.

Refleksi

Kegiatan di Siklus I sudah berjalan cukup baik. Tingkat ketuntasan belajar juga mengalami peningkatan meski belum terlihat secara signifikan. Permasalahan yang muncul pada pembelajaran Siklus I seperti, guru masih kurang maksimal dalam memberikan motivasi dan memberikan bimbingan saat kerja kelompok dan guru kurang aktif melibatkan siswa. Sedangkan siswa masih kurang aktif dan kurang memperhatikan guru. Siswa yang pandai lebih mendominasi saat kerja kelompok.

Adapun perbaikan untuk Siklus berikutnya adalah guru dalam memberikan motivasi perlu ditingkatkan dan lebih interaktif. Guru lebih aktif dalam bimbingan individu maupun kelompok dan lbih sering mengajak siswa dalam memanfaatkan media pembelajaran.

\section{Deskripsi Data Pelaksanaan Tindakan Siklus II}

Perencanaan

Pada tahap perencanaan telah direncanakan dan dipersiapkan hal-hal seperti, menyusun RPP dengan materi persebaran sumber daya alam di Indonesia, sesuai dengan reflesi Siklus II, kemudian mempersiapkan sumber dan media pembelajaran, selanjutnya menyiapkan alat evaluasi, dan yang terakhir menyiapkan lembar observasi Pelaksanaan

Siklus II dilaksanakan pada hari Selasa 11 Februari 2020 dengan alokasi waktu 2 jam pelajaran $(2 \times 35$ menit $))$. Pada saat pelaksanaan penelitian dilakukan oleh peneliti dan guru kelas IV sebagai observer untuk mengamati proses pembelajaran.

\section{Pengamatan}

Hasil pengamatan keterampilan guru: berdasarkan pengamatan keterampilan guru di Siklus II diperoleh hasil 3,2 berkategori baik. Keterampilan guru merancang RPP dengan metode Course Review Hooray memperoleh skor 4 berkategori sangat baik. RPP yang dirancang guru memuat SK dan KD, tujuan pembelajaran dan langkahlangkah pembelajaran, serta alat evaluasi. Hasil pengamatan terhadap aktivitas siswa, siswa memperoleh skor rata-rata sebesar 2,6 berkategori baik. Sikap antusias mengikuti pembelajaran mendapatkan skor rata-rata 2,6 berkategori baik. Pada awal pembelajaran sebagian besar siswa sudah menunjukkan sikap antusias dan sudah tidak canggung dalam pembelajaran. Keaktifan siswa menyampaikan pendapat mendapatkan skor 2,6 berkategori baik. Dalam menjawab pertanyaan pada saat kerja kelompok siswa memperoleh skor 2,7 berkategori baik.

Hasil Belajar Siswa

Tabel 5 Tabel Hasil Belajar Siklus II

\begin{tabular}{ccccc}
\hline No & Pencapaian & Data Awal & Siklus I & Siklus II \\
\hline 1. & Rata-rata & 52 & 66 & 71 \\
\hline 2. & Nilai Terendah & 25 & 40 & 50 \\
\hline
\end{tabular}




\begin{tabular}{lcccc}
\hline 3. & Nilai Tertinggi & 80 & 90 & 100 \\
\hline 4. & Tidak Tuntas & $67 \%$ & $56 \%$ & $33 \%$ \\
\hline 5. & Tuntas & $33 \%$ & $44 \%$ & $67 \%$ \\
\hline
\end{tabular}

Berdasarkan tabel analisis nilai rata-rata Siklus II adalah 77 dengan nilai tertinggi adalah 100 dengan nilai terendah 50. Pada Siklus ini ketuntasan belajar mengalami peningkatan sebesar $67 \%$. Meskipun terdapat peningkatan indikator keberhasilan belum tercapai, maka perlu dilakukan Siklus III.

\section{Refleksi}

Pada proses pembelajaran Siklus II terdapat peningkatan dalam keterampilan guru, aktivitas para siswa dan hasil belajar siswa. Siswa mulai menyesuaikan diri dengan Model Pembelajaran yang diterapkan. Tingkat ketuntasan belajar mengalami peningkatan. Siswa yang mencapai ketuntasan hasil belajar yaitu $67 \%$ sedangkan yang tidak tuntas mencapai 33\%, maka perlu dilakukan perbaikan selanjutnya. Adapun permasalahan yang muncul pada pembelajaran Siklus II seperti, guru hanya menyampaikan tujuan pembelajaran dan masih kurang memberikan motivas. Sedangkan siswa belum semuanya terlibat aktif dalam penggunaan media. Siswa kurang bekerjasama saat kelompok dan kurang aktif dalam menyampaikan pendapat. Adapun perbaikan di Siklus berikutnya adalah guru lebih memberikan motivasi agar siswa lebih bersemangat dam lebih variatif merencanakan kegiatan kelompok di Siklus III, serta lebih memberikan bimbingan kepada siswa.

\section{Deskripsi Data Pelaksanaan Tindakan Siklus III}

\section{Perencanaan}

Pada tahap perencanaan telah direncanakan dan dipersiapkan hal-hal seperti, menyusun RPP dengan materi pemanfaatan sumber daya alam dengan menggunakan Model Pembelajaran Secara Kooperatif Course Review Hooray sesuai dengan refleksi Siklus II, kemudian mempersiapkan sumber dan media pembelajaran, selanjutnya menyiapkan alat evaluasi, dan yang terakhir menyiapkan lembar observasi Pelaksanaan Siklus III dilaksanakan pada hari Kamis, 13 Februari 2020 dengan alokasi waktu 2 jam pelajaran $(2 \times 35$ menit $)$ Pelaksanaan penelitian dilakukan bersama guru kelas IV (observer) untuk mengamati proses pembelajaran.

\section{Pengamatan}

Hasil pengamatan terhadap keterampilan guru: berdasarkan pengamatan terhadap keterampilan guru di Siklus III diperoleh hasil 3,8 berkategori sangat baik. Keterampilan guru merancang RPP mendapatkan skor 4 berkategori sangat baik. guru merancang RPP dengan lengkap dan merancang kegiatan pembelajaran berdasarkan refleksi Siklus II. Pada keterampilan membuka pelajaran guru mendapatkan skor 4 berkategori sangat baik. Pada awal pembelajaran, guru memberikan motivasi, menyampaikan tujuan pembelajaran, memberikan kaitan tentang materi yang akan dibahas. Keterampilan bertanya dasar mendapatkan skor 4 berkategori sangat baik. Guru menggunakan bahasa dan petunjuk yang jelas selain itu pertanyaan diberikan secara merata. Skor keterampilan bertanya lanjut meningkat menjadi 3 berkategori baik. Pada keterampilan ini guru memberikan pertanyaan lanjutan dengan menyesuaikan tingkat kognitif, urutan pertanyaan, dan pertanyaan sudah menciptakan interaksi yang baik.

Hasil pengamatan terhadap aktivitas siswa: berdasarkan hasil pengamatan terhadap aktivitas siswa selama proses Siklus III, siswa memperoleh skor rata-rata sebesar 3,5 berkategori sangat baik. Sikap antusias mengikuti pembelajaran dengan menggunakan Model Course Review Hooray memperoleh skor rata-rata 3,5 berkategori sangat baik. Pada awal pembelajaran sebagian besar siswa menunjukkan sikap antusias dan bersemangat mengikuti pelajaran. Keaktifan siswa menyampaikan pendapat memperoleh skor rata-rata 3,5 berkategori sangat baik. 
Siswa aktif dan percaya diri menyampaikan pendapat bila dibandingkan dengan Siklus sebelumnya. Sedangkan keaktifan siswa menjawab pada saat kerja kelompok mendapatkan skor rata-rata 3,6 berkategori sangat baik.

Hasil Belajar Siswa

Tabel 6. Tabel Hasil Belajar Siklus II

\begin{tabular}{clcccc}
\hline No & Pencapaian & Data Awal & Siklus I & Siklus II & Siklus III \\
\hline 1. & Rata-rata & 52 & 66 & 71 & 82 \\
\hline 2. & Nilai Terendah & 25 & 40 & 50 & 50 \\
\hline 3. & Nilai Tertinggi & 80 & 90 & 100 & 100 \\
\hline 4. & Tidak Tuntas & $67 \%$ & $56 \%$ & $33 \%$ & $7 \%$ \\
\hline 5. & Tuntas & $33 \%$ & $44 \%$ & $67 \%$ & $93 \%$ \\
\hline
\end{tabular}

Berdasarkan tabel analisis nilai rata-rata Siklus III adalah 77 dengan nilai tertinggi mencapai 100 serta nilai terendah 50. Pada Siklus III hanya 7\% siswa yang belum tuntas, sedangkan siswa yang tuntas sudah mencapai $93 \%$.

Refleksi

Dari hasil pelaksanaan di Siklus III menunjukkan bahwa keterampilan guru, aktivitas, dan hasil belajar siswa menunjukkan peningkatan yang dramatis sehingga dapat disimpulkan bahwa: 1) Terdapat peningkatan pada penilaian keterampilan guru di Siklus III dengan nilai rata-rata mencapai 3,8 berkategori sangat baik, 2) Terdapat peningkatan pada penilaian aktivitas siswa di Siklus III dengan nilai ratarata mencapai 3,5 berkategori sangat baik, 3) Dari data ketuntasan hasil belajar menunjukkan bahwa di Siklus III dari jumlah 27 siswa terdapat 2 siswa yang dinyatakan tidak tuntas dengan persentase sebanyak 7\%. Sedangkan 25 siswa mencapai ketuntasan dengan persentase 93\% dengan nilai rata-rata 82 . Sehingga indikator keberhasilan sudah tercapai yaitu ketuntasan hasil belajar mencapai $75 \%$.

\section{Pembahasan}

Temuan penelitian didasarkan pada hasil observasi dan refleksi pada setiap Siklus. Pada penelitian ini proses pembelajaran IPS pada siswa kelas IV di SDN 10 Kepahiang memanfaatkan Model Pembelajaran Secara Kooperatif Course Review Hooray.

\section{Keterampilan Guru saat Pembelajaran}

Siklus I

Berdasarkan data keterampilan guru saat pembelajaran Siklus I diperoleh skor ratarata sejumlah 2,6 berkategori baik. Dalam merencanakan RPP guru memperoleh skor 4 berkategori sangat baik. Pada keterampilan membuka pelajaran guru memperoleh skor 3 berkategori baik. Guru memberikan motivasi dan penyampaian acuan tentang materi hanya disampaikan secara lisan sehingga siswa kurang memperhatikan. Pada keterampilan bertanya dasar memperoleh skor 3 berkategori baik. Guru memberikan pertanyaan dengan bahasa yang jelas hanya penyebaran kurang merata. Keterampilan bertanya lanjut memperoleh skor 2 berkategori kurang karena pertanyaan belum meningkatkan interaksi dalam pembelajaran. Keterampilan guru dalam memberikan penguatan memperoleh skor 3 berkategori baik, ini ditunjukkan dengan memberikan penguatan baik secara verbal maupun secara non verbal.

Pada keterampilan mengadakan variasi memperoleh skor 2 berkategori cukup karena siswa kurang dilibatkan dalam menggunakan media. Keterampilan menjelaskan guru memperoleh skor 3 berkategori baik, dalam pembelajaran guru menggunakan bahasa yang jelas. Pada keterampilan guru saat membimbing kelompok kecil memperoleh skor 3 berkategori baik, guru membimbing dan 
memberikan motivasi pada setiap kelompok. keterampilan mengelola kelas guru memperoleh skor 2 berkategori cukup. Ini dikarenakan guru kurang memberikan tekanan sehingga kurang memusatkan perhatian siswa. Pada keterampilan saat mengajar kelompok kecil dan perorangan memperoleh skor 2 berkategori cukup ini dikarenakan bimbingan secara perseorangan kurang diberikan secara merata. Hal ini disebabkan guru masih kurang maksimal dalam pembelajaran diantaranya guru masih kurang dalam memberikan motivasi kepada siswa dan belum mengaktifkan siswa dalam menggunakan media. Selain itu guru masih kurang memberikan bimbingan pada saat kerja kelompok dan belum memberikan pertanyaan secara menyebar. Sedangkan pada keterampilan menutup pelajaran guru memperoleh skor 2 berkategori cukup. Ini dikarenakan guru hanya meminta siswa untuk menyimpulkan materi yang sudah dipelajari dan memberikan Post-Test.

\section{Siklus II}

Keterampilan guru saat pembelajaran Siklus II memperoleh skor rata-rata sebessar 3,2 berkategori sangat baik. Dalam merencanakan RPP guru memperoleh skor 4 berkategori sangat baik. Pada keterampilan membuka pelajaran guru memperoleh skor 3 berkategori baik. Diawal pembelajaran guru sudah memberikan motivasi, menyampaikan tujuan pembelajaran, dan menarik perhatian siswa. Pada keterampilan bertanya dasar guru memperoleh skor 4 berkategori sangat baik. Ini ditunjukkan oleh memberikan pertanyaan secara jelas, menyebar, pemindahan giliran, dan pemberian waktu berpikir. Sedangkan pada keterampilan bertanya lanjut masih memperoleh skor 2 berkategori cukup, dikarenakan pertanyaan belum meningkatkan interaksi dan belum menggunakan pertanyaan pelacak. Pada keterampilan memberikan penguatan memperoleh skor 4 berkategori sangat baik, guru sudah memberikan penguatan secara verbal maupun secara non verbal kepada individu ataupun kelompok.

Keterampilan mengadakan variasi di Siklus II secara drastis meningkat dengan memperoleh skor 3 berkategori baik. Pada keterampilan ini guru menggunakan variasi suara, melibatkan siswa dalam menggunakan media, dan menumbuhkan interaksi dalam pembelajaran. Keterampilan menjelaskan memperoleh skor 3 berkategori baik, guru menggunakan bahasa yang jelas, menggunakan media, dan memberikan balikan. Pada keterampilan guru dalam membimbing kelompok kecil memperoleh skor 3 berkategori baik. Pada keterampilan ini guru memberikan motivasi, memusatkan perhatian, dan membimbing siswa rangkuman hasil diskusi. Keterampilan mengelola kelas guru memperoleh skor 2 berkategori cukup, guru memodifikasi tingkah laku dan memusatkan perhatian siswa. Pada keterampilan guru dalam mengajar kelompok kecil maupun perorangan memperoleh skor 3 berkategori baik. Guru memberikan bimbingan secara merata baik siswa yang pandai maupun yang kurang pandai. Sedangkan pada keterampilan penutup pelajaran memperoleh skor 3 berkategori baik. Pada akhir pembelajaran guru membimbing siswa membuat rangkuman, memberikan tindak lanjut, dan memberikan Post-Test.

\section{Siklus III}

Hasil pengamatan pada keterampilan guru di Siklus III didapatkan skor rata-rata sebesar 3,8 berkategori sangat baik. Pada Siklus ini keterampilan guru mengalami peningkatan yang signifikan. Pada Siklus III guru merencanakan RPP memperoleh skor 4 berkategori sangat baik. Guru merencanakan RPP secara lengkap meliputi materi disesuaikan dengan SK dan KD, menyampaikan tujuan pembelajaran, kegiatan pembelajaran, dan alat evaluasi. Pada keterampilan membuka pelajaran guru memperoleh skor 4 berkategori sangat baik. Guru memberikan motivasi agar perhatian siswa terpusat, menyampaikan tujuan pembelajaran, dan membuat kaitan dengan materi yang siap dipelajari. Keterampilan guru bertanya dasar memperoleh 
skor 4 berkategori sangat baik. Guru menggunakan bahasa yang jelas, penyebar, dan memberikan waktu berpikir dalam memberikan pertanyaan.

Keterampilan bertanya lanjut memperoleh skor 3 berkategori baik, pada keterampilan ini guru menyesuaikan pertanyaan dengan tingkat kognitif siswa. Selain itu guru sudah mengurutkan pertanyaan sehingga terjadi interaksi pada saat guru mengajukan pertanyaan. Pada keterampilan memberikan penguatan guru memperoleh skor 4 berkategori sangat baik. Guru sudah memberikan penguatan secara merata baik secara verbal maupun secara non verbal. Keterampilan guru dalam mengadakan variasi pembelajaran memperoleh skor 4 berkategori sangat baik, dengan mengadakan penyampaian yang jelas dan menggunakan media yang mengaktifkan siswa. Pada keterampilan guru dalam membimbing diskusi kelompok berskala kecil memperoleh skor 4 berkategori sangat baik. Guru sudah memusatkan perhatian siswa serta memberikan bimbingan secara merata agar siswa aktif dalam kerja kelompok.

Keterampilan mengelola kelas memperoleh skor 4 berkategori sangat baik, guru menunjukkan sikap tanggap dan memusatkan perhatian kelompok seta modifikasi tingkah laku. Pada keterampilan guru dalam mengajar kelompok kecil maupun perorangan guru memperoleh skor 4 berkategori sangat baik. Guru memberikan pendekatan secara merata dan memberikan bimbingan khusus baik kepada siswa yang sudah pandai maupun siswa yang kurang pandai. Sedangkan keterampilan menutup pelajaran guru memperoleh skor 4 berkategori sangat baik. Pada akhir pembelajaran guru membimbing siswa dalam menyimpulkan materi dan mengaplikasikan ide baru, memberikan tindak lanjut serta memberikan Post-Test untuk mengukur pemahaman siswa.

Berdasarkan data yang sudah dijabarkan dapat disimpulkan bahwa dalam setiap Siklus keterampilan guru mengalami peningkatan. Ini membuktikan bahwa dengan menggunakan Model Pembelajaran Secara Kooperatif Course Review Hooray dapat meningkatkan keterampilan guru disaat pembelajaran. Djamarah (2005) mendefinisikan keterampilan dasar mengajar yaitu keterampilan yang mutlak harus dipenuhi guru, dengan keterampilan dasar mengajar diharapkan guru mampu mengoptimalkan peranannya saat didalam kelas. Menurut Mulyasa (2009) dari segi proses guru bisa dikatakan berhasil apabila dalam pengajaran mampu melibatkan secara aktif sebagian besar siswa baik secara fisik, mental, dan sosial selama proses pembelajaran. Sedangkan dari hasil guru bisa dikatakan berhasil jika pembelajaran mampu mengubah perilaku siswa kearah penguasaan kompetensi dasar. Usaha yang dilakukan guru agar pembelajaran dapat berhasil diantaranya menguasai keterampilan dasar mengajar dan kemampuan mengembangkan pembelajaran yang inovatif.

\section{Aktivitas Siswa saat Pembelajaran \\ Siklus I}

Berdasarkan hasil pengamatan terhadap aktivitas siswa di Siklus I diperoleh skor rata-rata 2,3 berkategori baik. Sikap antusias siswa mengikuti pembelajaran memperoleh skor rata-rata 2,2 berkategori baik. pada aspek ini sebagian besar siswa belum dapat memusatkan perhatian sehingga suasana kelas kurang terkontrol. Hal ini dikarenakan siswa masih canggung dalam mengikuti pembelajaran. Keaktifan siswa menyampaikan pendapat memperoleh skor rata-rata 2,1 berkategori baik. Pada aspek ini siswa yang aktif menjawab hanya didominasi oleh siswa yang pandai sedangkan siswa yang lain masih malu-malu menyampaikan pendapat. Keaktifan siswa menjawab pertanyaan pada saat kerja kelompok memperoleh skor rata-rata 2,3 berkategori baik. Siswa pandai yang lebih mendominasi pada saat menjawab pertanyaan dalam kelompok Course Review Hooray sedangkan yang lain harus ditunjuk oleh guru terlebih dahulu. 
Kerjasama siswa dalam kelompok memperoleh skor rata-rata 2,3 berkategori baik. Pada aspek ini siswa sudah mulai menunjukkan kerjasama antar anggota meskipun masih terlihat sebagian siswa yang masih individual dalam kelompok. Sikap sportif saat kerja kelompok skor rata-rata 2,4 berkategori baik. Sikap sportif ditunjukkan beberapa siswa sudah mematuhi aturan-aturan kerja kelompok seperti menghitung skor yang diperoleh. Meski demikian masih ditemukanbeberapa siswa yang belum berkesempatan mengemukakan pendapat dan belum menunjukkan bersikap tanggung jawab. Kemampuan menyimpulkan materi memperoleh skor rata-rata 2,3 berkategori baik. Beberapa siswa sudah mampu menyimpulkan materi yang dipelajari tetapi lebih banyak siswa yang masih kurang mampu menyimpulkan materi.

\section{Siklus II}

Aktivitas siswa di Siklus II mengalami peningkatan. Pada aktivitas siswa skor ratarata yang diperoleh sebesar 2,6 berkategori baik. Pada Siklus II sikap antusias mengikuti pembelajaran memperoleh skor rata-rata 2,6 berkategori baik. Siswa sudah menunjukkan sikap antusias seperti senang mengikuti pelajaran dan kondisi kelas terkontrol. Tetapi masih ditemukan beberapa siswa yang asyik bermain sendiri dan tidak memperhatikan guru. Keaktifan siswa menyampaikan pendapat menghasilkan skor rata-rata sebesar 2,6 berkategori baik. Pada aspek ini sebagian besar siswa tidak malu-malu menyampaikan pendapat maupun bertanya kepada guru. Sedangkan keaktifan siswa menjawab pada saat kerja kelompok menghasilkan skor rata-rata sebesar 2,7 berkategori baik. siswa yang sebelumnya masih malumalu, di Siklus ini sudah menunjukkan keaktifan menjawab pada saat kerja kelompok.

Kerjasama siswa dalam kerja kelompok mendapatkan skor rata-rata sebesar 2,6 berkategori baik. Kerjasama dalam kelompok sudah nampak antar anggota tetapi masih juga ada siswa yang pasif dalam kerja kelompok. Sikap sportif siswa saat kerja kelompok memperoleh skor rata-rata 2,6 berkategori baik. Pada aspek ini siswa sebagian besar tidak berlaku curang, sudah mulai membagi kesempatan menyampaikan pendapat antar anggota dan sebagian siswa yang sudah menunjukkan sikap tanggung jawab. Kemampuan siswa menyimpulkan materi memperoleh skor rata-rata 2,5 berkategori baik. Pada kegiatan akhir sebagian besar siswa sudah mampu menyimpulkan materi dan tidak didominasi lagi oleh siswa yang pandai.

\section{Siklus III}

Pada Siklus III aktifitas siswa mengalami peningkatan yang dramatis yaitu skor rata-rata pada aktivitas siswa mencapai 3,5 berkategori sangat baik. Antusias siswa mengikuti pembelajaran dengan Model Pembelajaran Secara Kooperatif Course Review Hooray memperoleh skor rata-rata 3,5 berkategori sangat baik. Siswa senang mengikuti pembelajaran, perhatian terpusat, dan aktif dalam pembelajaran. Keaktifan siswa menyampaikan pendapat memperoleh skor rata-rata 3,5 berkategori sangat baik. Pada aspek ini siswa aktif menyampaikan pendapat, sering bertanya, dan menunjukkan sikap tanggap. Sedangkan keaktifan siswa menjawab pertanyaan pada saat kerja kelompok memperoleh skor rata-rata sebesar 3,6 berkategori sangat baik. Pada saat kerja kelompok sebagian besar siswa mampu menjawab pertanyaan dengan percaya diri dan jawaban tepat.

Kerjasama siswa dalam kelompok memperoleh skor rata-rata sebesar 3,6 berkategori sangat baik. Pada Siklus III sebagian besar siswa menunjukkan saling bekerjasama sehingga menciptakan interaksi yang positif antar anggota. Sikap sportif saat kerja kelompok memperoleh skor rata-rata 3,5 berkategori sangat baik. Pada saat kerja kelompok siswa menunjukkan sikap positif seperti mematuhi aturan kerja kelompok, 
pembagian tugas antar anggota, dan menunjukkan sikap tanggung jawab. Kemampuan siswa dalam menyimpulkan materi yang sudah dipelajari memperoleh skor rata-rata sebesar 3,6 berkategori sangat baik. Ini terlihat di akhir pembelajaran siswa mampu menyimpulkan materi, mengeksplorasi pendapat sendiri, mengaplikasikan ide, dan mampu menjawab soal Post-Test.

Berdasarkan data di atas terdapat peningkatan aktivitas siswa pada tiap Siklus setelah menerapkan Model Pembelajaran Secara Kooperatif Course Review Hooray. Dengan pembelajaran kooperatif maka menuntut siswa untuk aktif bekerja dalam kelompok dan mampu meningkatkan hasil belajar siswa. Menurut Slavin (2010) bahwa penggunaan pembelajaran kooperatif antara lain dapat meningkatkan pencapaian prestasi siswa dan juga memiliki dampak positif yang bisa mengembangkan hubungan antar kelompok, penerimaan teman sekelas terhadap yang lemah dalam akademik, dan meningkatkan rasa percaya diri. Pembelajaran kooperatif berjalan dengan baik dan dapat diaplikasikan untuk semua jenis kelas baik kelas khusus untuk anak berbakat, kelas pendidikan khusus dan bahkan untuk kelas yang tingkat kecerdasannya rata-rata dan khususnya sangat. Proses pembelajaran mengutamakan keaktifan siswa karena akan tercipta interaksi antar guru dengan siswa dan antar siswa dengan siswa. Interaksi ini mengakibatkan terbentuknya kompetensi dasar yang mengarah pada hasil belajar siswa.

\section{Hasil Belajar Siswa}

Berdasarkan data hasil belajar siswa di Siklus I rata-rata nilai mencapai 66 dengan nilai terendah 40 dan nilai tertinggi 90 . Dengan persentase dalam ketuntasan belajar mencapai $44 \%$, maka dapat dikatakan bahwa di Siklus ini tidak berhasil. Pada Siklus II, nilai rata-rata para siswa meningkat dari 66 menjadi 71 persentase ketuntasan belajar meningkat mencapai $67 \%$. Meskipun nilai rata-rata dan prosentase ketuntasan belajar meningkat tetapi masih belum mencapai indikator keberhasilan sebesar $75 \%$. Pada Siklus III terdapat peningkatan secara signifikan yaitu rata-rata nilai menjadi 82 dan persentase ketuntasan belajar meningkat mencapai 93\%. Peneliti menetapkan bahwa penelitian ini sudah mencapai indikator keberhasilan yaitu ketuntasan belajar mencapai $75 \%$.

Setelah mengkaji data di atas membuktikan bahwa dengan menggunakan Model Pembelajaran Secara Kooperatif Course Review Hooray dapat meningkatkan hasil belajar. Menurut Anni (2006) hasil belajar adalah perubahan atas tingkah laku yang dialami siswa setelah melewati suatu aktivitas belajar. Keberhasilan dalam belajar sangat dipengaruhi beberapa faktor. Faktor-faktor tersebut dapat dibagi menjadi dua kelompok; Faktor Intern dan Faktor Ekstern. Faktor Intern atau faktor dari dalam yang sangat berpengaruh atas hasil belajar yaitu kecakapan, minat, usaha, bakat, motivasi, kelemahan, perhatian, dan kebiasaan siswa, serta kesehatan. Sedangkan Faktor Ekstern atau faktor dari luar yang sangat berpengaruh terhadap hasil belajar diantaranya lingkungan fisik serta non fisik, lingkungan keluarga, lingkungan sosial dan budaya, lingkungan sekolah, guru, serta pelaksana pembelajaran, dan teman-teman sekolah.

\section{Implikasi hasil penelitian}

Model Pembelajaran Secara Kooperatif menurut Solihatin dan Raharjo (2007), memiliki pengertian sebagai sebuah sikap atau perilaku dalam bekerja dan juga membantu antara sesama dalam kerjasama yang teratur secara berkelompok, dimana keberhasilan kerja dipengaruhi oleh keterlibatan seluruh anggota. Pembelajaran Course Review Hooray adalah salah satu pembelajaran secara kooperatif dengan cara mengelompokan siswa dalam suatu kelompok-kelompok kecil yang menyenangkan. Pada pembelajaran menggunakan model Course Review Hooray, aktifitas dalam belajar lebih banyak terpusat kepada siswa. Pada proses pembelajaran, guru bertindak sebagai pemberi informasi, pembimbing, dan 
fasilitator. Suasana belajar serta interaksi yang menyenangkan mampu membuat siswa menikmati pelajaran dan tidak membosankan. Kualitas pembelajaran dapat diartikan sebagai sebuah keterkaitan sistemik dan sinergis guru, siswa, kurikulum serta bahan belajar, fasilitas, media, dan sistem pembelajaran untuk menghasilkan sebuah proses dan sebuah hasil belajar yang paling optimal sesuai dengan tuntutan kurikuler.

Pada pembelajaran IPS di SD Negeri 10 Kepahiang dengan memanfaatkan Model Pembelajaran Secara Kooperatif Course Review Hooray dinilai dapat meningkatkan kualitas pembelajaran. Peningkatan ini meliputi keterampilan guru dalam kelas, aktivitas siswa dalam pembelajaran, serta hasil belajar siswa. Peran guru dalam pembelajaran sebagai pembimbing, fasilitator, dan simulator sehingga menciptakan iklim pembelajaran yang hangat dengan siswa. Dengan terciptanya iklim pembelajaran tersebut maka siswa lebih terdorong untuk aktif dalam pembelajaran yang akan berimbas kepada hasil belajar siswa.

Aktivitas siswa pada pembelajaran IPS dengan menggunakan Model Pembelajaran Secara Kooperatif Course Review Hooray terlihat aktif dalam pembelajaran. Keaktifan siswa meliputi aktif mengemukakan pendapat, aktif dalam kerja kelompok serta antusias mengikuti pembelajaran. Model Pembelajaran Secara Kooperatif tipe Course Review Hooray menyajikan suatu pembelajaran yang menyenangkan bagi siswa selain itu juga mengaktifkan siswa dalam pembelajaran.

Melalui Model Pembelajaran Secara Kooperatif Course Review Hooray mampu meningkatkan hasil belajar pada siswa yang meliputi ranah kognitif, ranah afektif, dan ranah psikomotorik. Dari ranah kognitif ditunjukkan bahwa hasil belajar pada siswa mengalami suatu peningkatan yang mana nilai rata-rata sudah di atas KKM. Dari ranah afektif menunjukkan bahwa adanya perubahan sikap yang lebih baik. Diantaranya sikap antusias mengikuti pembelajaran, sikap menghargai pendapat, dan aktif dalam kegiatan kelompok.

Sedangkan dari ranah psikomotorik menunjukkan bahwa keterampilan siswa mengalami peningkatan, seperti keterampilan mengerjakan tugas kelompok, berdiskusi, keterampilan menjawab, dan sebagainya. Dengan demikian dapat disimpulkan bahwa dengan menggunakan Model Pembelajaran Secara Kooperatif Course Review Hooray mampu meningkatkan kualitas pembelajaran meliputi keterampilan guru didalam kelas, aktivitas siswa saat pembelajaran, dan peningkatan hasil belajar siswa.

\section{Simpulan}

Berdasarkan hasil Penelitian Tindakan Kelas penerapan Model Pembelajaran Secara Kooperatif Course Review Hooray pada siswa kelas IV SD Negeri 10 Kepahiang dapat disimpulkan sebagai berikut; Dengan adanya perbaikan pembelajaran, keterampilan guru dalam pelaksanaan pembelajaran mengalami peningkatan. 2) Pembelajaran lebih terpusat pada siswa sehingga guru cukup berperan sebagai pembimbing, fasilitator, dan dinamisator dalam pembelajaran. Peningkatan keterampilan guru didalam kelas pada Siklus I ditunjukkan dengan skor rata-rata sebesar 2,6 berkategori baik, di Siklus II meningkat menjadi 3,2 berkategori sangat baik dan di Siklus III mencapai puncaknya di 3,8 berkategori sangat baik.

Aktivitas siswa saat pembelajaran juga menunjukkan peningkatan, diantaranya siswa tampak lebih antusias serta lebih aktif saat pembelajaran. Peningkatan ini juga tampak dalam skor rata-rata di Siklus I sebesar 2,3 berkategori baik. Pada Siklus II skor rata-rata meningkat menjadi 2,6 berkategori baik. Dan pada Siklus III skor rata-rata mencapai 3,5 berkategori sangat baik. Hasil belajar siswa 
menunjukkan peningkatan yang pesat pada setiap Siklusnya. Persentase ketuntasan siswa dalam belajar di Siklus I sebesar 44\%, di Siklus II sebesar 67\%, dan di Siklus III sebesar 93\%. Dengan demikian bisa ditarik sebuah kesimpulan bahwa dengan penerapan Model Pembelajaran Secara Kooperatif Course Review Hooray kualitas pembelajaran IPS mengalami peningkatan secara mengesankan.

Berdasarkan simpulan yang telah dijabarkan, maka saran dalam penelitian ini adalah 1) Guru hendaknya mampu menciptakan dan menerapkan Model Pembelajaran yang menarik serta inovatif dan menguasai keterampilan mengajar agar aktivitas dan hasil belajar siswa meningkat. Salah satunya dengan menggunakan Model Pembelajaran Secara Kooperatif Course Review Hooray, 2) Usaha untuk meningkatkan aktivitas siswa dalam pembelajaran yaitu dengan menerapkan Model Pembelajaran yang mengutamakan kerjasama dan iklim pembelajaran yang menyenangkan salah satunya Model Pembelajaran Secara Kooperatif Course Review Hooray, 3) Upaya dalam meningkatkan hasil belajar tidak lepas dari peran guru, maka guru hendaknya dalam menanamkan konsep mengutamakan keaktifan siswa, kerjasama antar siswa, dan iklim pembelajaran yang menyenangkan bagi siswa, 4) Sekolah hendaknya lebih ikut mendukung meningkatkan kualitas pembelajaran baik dukungan secara fisik maupun secara non fisik. Diantaranya memfasilitasi sarana prasarana pembelajaran yang menunjang sehingga dapat mendukung guru untuk menerapkan Model Pembelajaran yang inovatif.

\section{Referensi}

Anni, C. T. (2006). Psikologi Belajar. Semarang: UPT MKK UNNES.

Aksiwi, R., D., D. \& Endra, M., S. (2014). Implementasi Metode Pembelajaran Course Review Horay untuk Meningkatkan Aktivitas dan Hasil Belajar Jurnal Penyesuian. Jurnal Pendidikan Akutansi Indonesia, XII, 1, 36-47.

Anggraeni, D. (20110. Peningkatan Kualitas Pembelajaran IPS Melalui Model Pembelajaran Kooperatif Tipe Course Review Horay pada Siswa Kelas IV SD Negeri Sekaran 01 Semarang. Jurnal Kependidikan Dasar KREATIF, 1(2), 194-205.

Aqib, Z. (2008). Penelitian Tindakan Kelas. Bandung: Yrama Widya.

Djamarah, S., B. (2005). Guru dan Anak Didik dalam Interaksi Edukatif. Jakarta: Renika Cipta.

Gulo, W. (2002). Metodologi Penelitian. Jakarta: PT. Gramedia Widiasarana Indonesia.

Hidayati, M. \& Anwar, S. (2008). Pengembangan Pendidikan IPS SD. Jakarta: Direktorat Jendral Pendidikan Tinggi Departemen Pendidikan Nasional.

Mulyasa, E. (2009). Menjadi Guru Yang Profesional Menciptakan Pembelajaran Kreatif dan Menyenangkan. Bandung: Remaja Rosdakarya.

Pebriansyah, PBN. (2009). Upaya Peningkatan Prestasi Belajar Siswa Kelas VIIIA SMPN 1 Ngawen pada Mata Pelajaran IPS Materi Sejarah melalui Penerapan Model Pembelajaran Course Review Hooray Tahun Pelajaran 2008-2009. Semarang: FIS UNNES.

Poerwati, E. (2008). Assesmen Pembelajaran. Jakarta: Direktorat Jendral Pendidikan Tinggi Departemen Pendidikan Nasional.

Slavin, R., E. (2010). Cooperative Learning Teori, Reset dan Praktik. Bandung: Nusamedi.

Solihatin \& Raharjo. (2007). Cooperative Learning (Analisis Pembelajaran IPS). Jakarta: Bumi Aksara.

Subyantoro. (2009). Penelitian Tindakan Kelas. Semarang. Universitas Diponegoro. 